\title{
Édouard Brissaud: distinguished neurologist and Charcot's pupil
}

\author{
Édouard Brissaud: distinto neurologista e pupilo de Charcot \\ Paula Teixeira Marques ${ }^{1}$, Francisco Manoel Branco Germiniani', Carlos Henrique Ferreira Camargo², \\ Renato Puppi Munhoz³, Hélio Afonso Ghizoni Teive'
}

\begin{abstract}
Professor Charcot had several pupils in his famous neurological service at the Salpêtrière Hospital in Paris, France. Among them, Édouard Brissaud was one of Charcot's favorite pupils, temporarily becoming his successor after Charcot's death. Brissaud's neurological contributions were significant, including the description of hemifacial spasm, "geste antagoniste" in dystonia, pseudobulbar affect, post-traumatic stress disorder, the Brissaud-Sicard syndrome, and Brissaud's sign. Additionally, Brissaud was the first to suggest that Parkinson's disease pathology could be related to the substantia nigra.
\end{abstract}

Keywords: neurology; history of medicine; hemifacial spasm.

\section{RESUMO}

Professor Charcot teve vários discípulos em seu famoso serviço de neurologia no hospital Salpêtrière, em Paris, França. Dentre eles, Édouard Brissaud foi um dos pupilos favoritos de Charcot. Após a morte de Charcot, em 1893, Brissaud foi o seu sucessor temporário. Suas contribuições neurológicas foram muito expressivas, incluindo a descrição do espasmo hemifacial, do "geste antagoniste", da paralisia pseudobulbar, do transtorno de estresse pós-traumático, a síndrome de Brissaud-Sicard, e também do sinal de Brissaud. Além disso, Brissaud, sugeriu pela primeira vez no mundo, que a patologia da doença de Parkinson poderia estar relacionada à substância negra.

Palavras-chave: neurologia; história da medicina; espasmo hemifacial.

Jean-Martin Charcot (1825-1893), considered the founder and "father" of modern neurology, mentored several pupils during the second half of the 19th century at the "Mecca of Neurology" of the time, La Salpêtrière Hospital in Paris ${ }^{1,2}$. From 1862 to 1893 , Charcot had 32 house officers (internes), including renowned figures such as Bouchard (1864 to 1866), Bourneville (1868), Joffroy (1869), Pitres (1876), Brissaud (1879), Marie (1882), Gilles de la Tourette (1884), Guinon (1885), and Jean-Baptiste Charcot (1891), his own son ${ }^{1}$. In addition, Charcot had several specialist registrars (chefs de clinique), who eventually became his disciples, among them Marie (1883-1884), Babinski (1885-1886), Gilles de la Tourette (1887-1888), and Guinon $(1889-1890)^{1}$. Of these, Marie, Babinski, Tourette, and Brissaud were his favourite disciples, and Brissaud particularly, became a very close pupil of $\mathrm{Charcot}^{1,2,3}$, and is the subject of this review.

\section{ÉDOUARD BRISSAUD - A SHORT BIOGRAPHY}

Édouard Brissaud (1852-1909) (Figure 1) was born in Besançon, France, into a family of intellectuals and artists (actors and musicians) ${ }^{4,5,6}$. The most well known were his great-grandfather Jacques-Marie Boutet de Monvel, nicknamed "The Great Monvel", his great aunt Mademoiselle Mars, and his cousin Marie Dorval, among others. Brissaud is described as a well-educated, intelligent physician and a practical joker ${ }^{4,5,6}$. His medical career, in summary, confirmed that he was a nonresident medical student in 1872, and later, under the supervision of Professor Charcot, a neurology resident in 1875 , and doctor of medicine in $1880^{4,5,6}$. As well, he was the house officer at the La Salpêtrière Hospital in 1889. His career was markedly influenced by Professor Charcot, and he became a distinguished neurologist in Paris, France, despite being ignored

\footnotetext{
'Universidade Federal do Paraná, Hospital de Clínicas, Departamento de Medicina Interna, Unidade de Distúrbios do Movimento, Serviço de Neurologia, Curitiba PR, Brasil;

${ }^{2}$ Universidade Estadual de Ponta Grossa, Hospital Universitário, Serviço de Neurologia, Ponta Grossa PR, Brasil;

${ }^{3}$ University of Toronto, Toronto Western Hospital, Centre for Movement Disorders, Toronto, ON, Canada.

Correspondence: Hélio Afonso Ghizoni Teive; Rua General Carneiro 1103/102; 80060-150 Curitiba PR, Brasil. E-mail: hagteive@mps.com.br

Conflict of interest: There is no conflict of interest to declare.

Received 18 February 2018; Received in final form 13 April 2018; Accepted 19 April 2018.
} 
internationally ${ }^{4,5,6}$. In 1893, Brissaud founded the journal Revue Neurologique, along with Charcot and Marie, published an atlas of the human brain, the famous medical handbook (Traité de Médicine), supported by Charcot and Bouchard, and a book of popular medical expressions ${ }^{4,5,6}$. Brissaud also wrote a comedy play entitled "Le chèque". Brissaud was an attending doctor to the famous French writer Marcel Proust, and it is well known that Dr. du Boulbon, a character in Proust's masterpiece " $A$ la recherché du temps perdu", was inspired by him., ${ }^{4,6,7}$

"So, as happens whenever remarks we have heard about someone we do not know have managed to awaken in us the idea of a great talent, of some kind of genius, in my innermost thoughts I now conferred upon $\mathrm{Dr} d u$ Boulbon that unbounded confidence, which is inspired in us by the man who, with greater acuity than his fellows, perceives the truth. It is true that I knew him to be more of a specialist in nervous diseases, the man to whom Charcot, before his death, had predicted that he would be the foremost authority in neurology and psychiatry (p. 265)"?

Brissaud was considered by some to be one of Charcot's favorite students: Poirier and Ricou stated, using a quotation of the late Professor Signoret, that "Brissaud was undoubtedly Charcot's favorite disciple" (Figure 2) ${ }^{3}$. Unfortunately, Brissaud died prematurely in 1909, before achieving his full potential in neurology $y^{3,4,5,6}$.

\section{BRISSAUD AND THE SUCCESSOR TO CHARCOT}

At the height of his career, internationally famous and 67 years old, Charcot died suddenly on August 16th, 1893, of acute pulmonary edema secondary to myocardial infarction, while on a trip with some of his assistants, including Professor Debove and Straus, to the French countryside (Morvan, a rural lake district in Burgundy, southeast of Paris) ${ }^{2}$. After Charcot's death, Brissaud acted as the temporary successor to Charcot's chair, from October 1893 to March 1894, when the permanent successor was chosen ${ }^{3,4,5,6}$.

The choice of a permanent successor to Charcot started in March of 1894 and three candidates were officially named. Fulgence Raymond was the eldest of Charcot's interns and associates at the Salpêtrière Hospital. Jules Dejerine was a distinguished neurologist from outside the Salpêtrière, and considered an enemy of Charcot. Brissaud was the youngest of the candidates. On March $15^{\text {th }}, 1894$, the faculty confirmed that Professor Fulgence Raymond was the winner ${ }^{4}$. Brissaud went on to have a brilliant university career and became the chair of history of medicine, as well as, later, for medical pathology. Raymond died 16

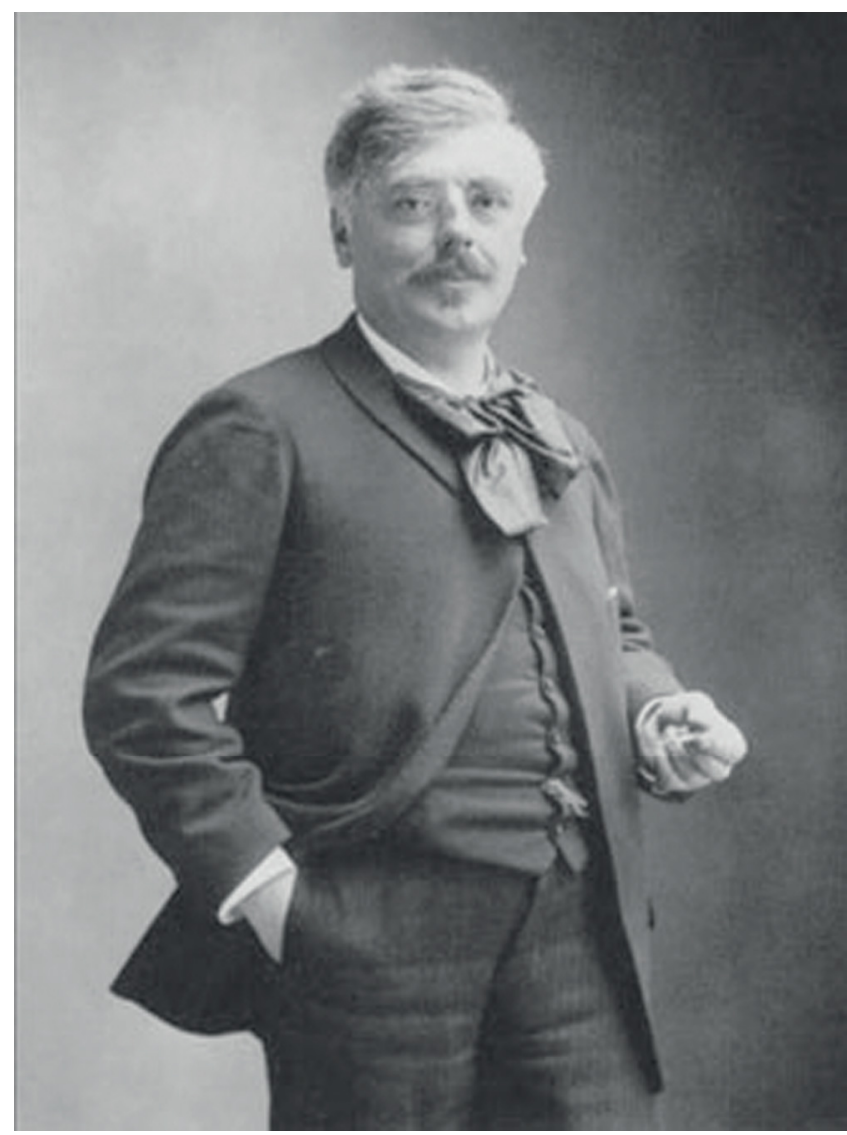

(Extracted from Google Images: Worldpress.com, February, 05 ${ }^{\text {th }}, 2018$ ) Figure 1. Professor Edouard Brissaud (1852-1909).

years later and Jules Dejerine became the third occupant of Charcot's chair. Pierre Marie became the next chair, after the Dejerine's death in $1917^{4,5,6,8}$.

\section{BRISSAUD'S MOST IMPORTANT CONTRIBUTIONS TO NEUROLOGY}

In 1893, Brissaud described the first case report of a patient with hemifacial spasm or "spams cloniques de la face $^{\text {s,10.10 }}$. Brissaud reported on a 35-year-old woman with clonic contractions on the right side if her face, involving the facial muscles, including the frontal, the orbicularis oculi, the zygomaticus, and the platysma (Figure 3). He also suggested several possible etiologies for hemifacial spasm including the presence of arterial malformations compressing the facial nerve ${ }^{9,10}$. Additionally, Brissaud made a differential diagnosis of hemifacial spasm with tics, and observed that the spasms worsened when the patient talked or was under stress ${ }^{9,10}$. In 1894, in his lecture on nervous disease that took place in the La Salpêtrière Hospital, Brissaud suggested for the first time that Parkinson's disease pathology was related to the substantia nigra, a scientific observation confirmed 25 years later by Tretiakoff ${ }^{11}$. In the field of movement disorders, Brissaud also introduced the term "mental 


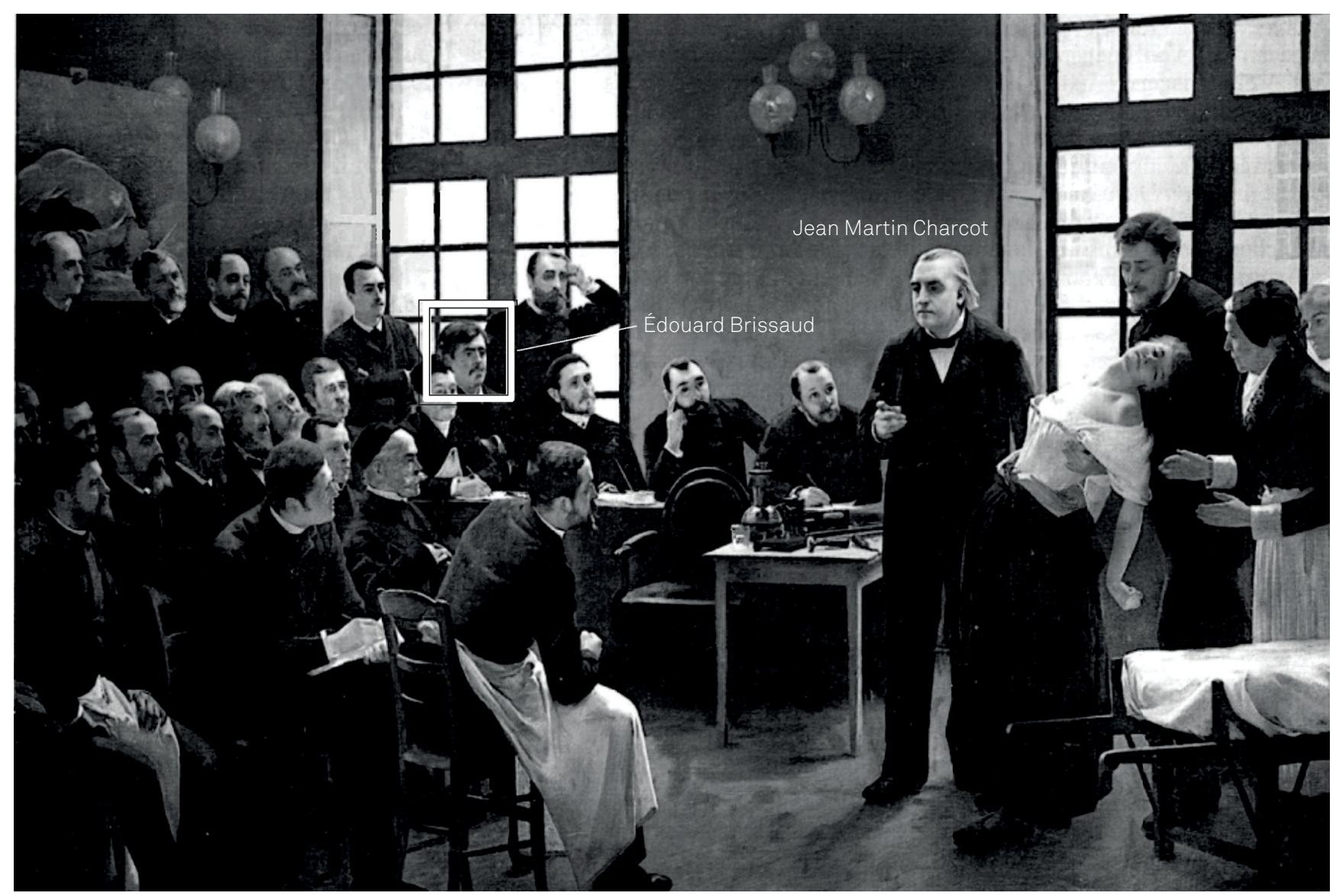

(Extracted from Google Images: www.en.wikipedia.org, October, 8 ${ }^{\text {th }}$, 1016).

Figure 2. Brissaud as an intern of Professor Jean-Martin Charcot a La Salpêtrière. Une leçon clinique à La Salpêtrière by Louis Brouillet.

torticollis", a focal form of dystonia, and described the "geste antagoniste", nowadays also known as a sensory trick ${ }^{12,13}$. Finally, Brissaud described the pseudobulbar affect, calling it "rire et pleurer spasmodique", the post-traumatic stress disorder, the Brissaud-Sicard syndrome (a pontine-crossed syndrome with ipsilateral hemifacial spasm and contralateral hemiparesis), and the Brissaud sign, a succedaneum of the Babinski sign ${ }^{14,15,16,17,18}$.

\section{CONCLUSION}

Brissaud was a brilliant neurologist at the Charcot School in Salpêtrière. In spite of being less famous than Charcot's other students, Brissaud was recognized at the time by his talent and friendship with the master and his family. Brissaud's collaborations on neurological science were very important, mainly those related to movement disorders.

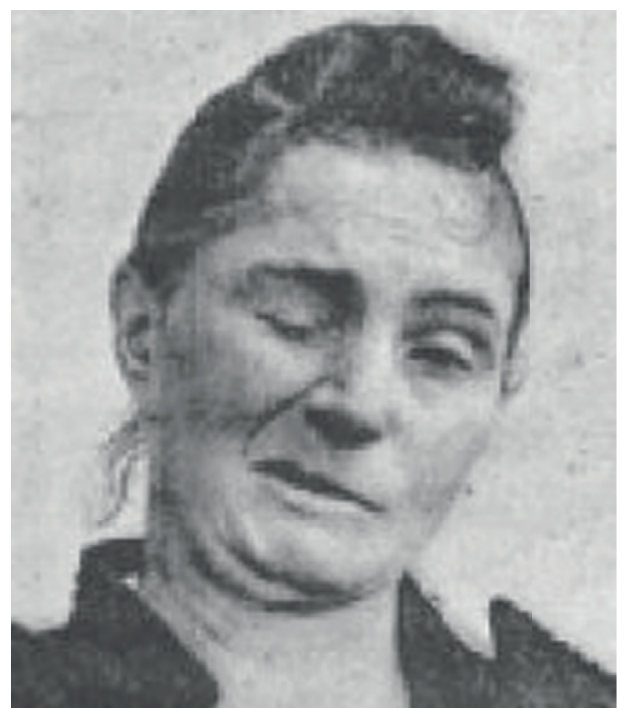

(Extracted from Brissaud $\left.{ }^{9}\right)$

Figure 3. Portrait of the woman with hemifacial spasm described by Brissaud.
Walusinski O. Jean-Martin Charcot's house officers at La Salpêtrière hospital. Front Neurol Neurosci. 2011;29:9-35. https://doi.org/10.1159/000321774
2. Teive HA, Marques P, Germiniani FM, Walusinski O. Requiem for a neurologist: the funeral rites of Jean-Martin Charcot. Arq Neuropsiquiatr. 2017 Nov;75(11):827-9. https://doi.org/10.1590/0004-282×20170144 
3. Poirier J, Ricou P. [Edouard Brissaud (1852-1909), Charcot's favorite pupil]. Hist Sci Med. 2010 Jul-Sep;44(3):247-55. French.

4. Tatu L. Édouard Brissaud, Fulgence Raymond and the succession of Charcot. Front Neurol Neurosci. 2011;29:52-60. https://doi.org/10.1159/000321776

5. Souques AN. crologie. Edouard Brissaud (1852-1909). Rev Neurol (Paris). 1910;19:1-4.

6. Poirier J. [Edouard Brissaud, a neglected neurologist and an artist at heart]. Bull Acad Natl Med. 2010 Jan;194(1):163-75. French.

7. Proust M. In search of lost time: the guermantes way. London: Penguin Books; 2005. Vol. 3.

8. Paciaroni M, Bogousslavsky J.Jules Joseph Déjerine versus Pierre Marie. Front Neurol Neurosci. 2011;29:162-9. https://doi.org/10.1159/000321784

9. Brissaud E. Vingt-quatrième leçon, Tics et spasms cloniques de la face. In: Meige $\mathrm{H}$, editor. Leçons sur les maladies nerveuses: La Salpêtriére, (1893-1894).

Paris: Masson; 1895. p. 502-20.

10. Colosimo C, Berardelli A. An early image of hemifacial spasm: edouard Brissaud contribution. Mov Disord. 2010 Apr;25(5):531-3. https://doi.org/10.1002/mds.22998
11. Brissaud E. Vingt-troisème leçon, Nature et pathogénie de la Maladie de Parkinson. In: Meige H, editor. Leçons sur les maladies nerveuses: La Salpêtrière,, (1893-1894). Paris: Masson; 1895

12. Poisson A, Krack P, Thobois S, Loiraud C, Serra G, Vial C et al. History of the 'geste antagoniste' sign in cervical dystonia.J Neurol. 2012 Aug;259(8):1580-4. https://doi.org/10.1007/s00415-011-6380-7

13. Broussolle E, Laurencin C, Bernard E, Thobois S, Danaila T, Krack P. Early illustrations of geste antagoniste in cervical dystonia and generalized dystonia. Tremor Other Hyperkinet Mov (N Y). 2015 Sep;5:332. https://doi.org/10.7916/D8KD1X74

14. Brissaud E, Sicard J. A l'hémispasme facial alterne. Presse Médicale 1908;16:234-6.

15. Tacik P, Krasnianski M, Alfieri A, Dressler D. Brissaud-Sicard syndrome caused by a diffuse brainstem glioma. A rare differential diagnosis of hemifacial spasm. Acta Neurochir (Wien). 2014 Feb;156(2):429-30. https://doi.org/10.1007/s00701-013-1984-6

16. Brissaud E. Le réflexe du fascia lata. Gaz Hebdo Med Chirurg. 1896;43:253-6.

17. Aguiar T, Maranhão Filho P. The Brissaud sign. Arq Neuropsiquiatr. 2014 Jun;72(6):471. https://doi.org/10.1590/0004-282X20140052

18. Nóbrega FR, Macêdo PJ, Vasconcellos LF. Teaching Video Neurolmages: missing toe: the relevance of the Brissaud reflex. Neurology. 2017 Aug;89(8):e97. https://doi.org/10.1212/WNL.0000000000004263 